\title{
KEBIJAKAN FORMULASI SANKSI KEBIRI KIMIA DI INDONESIA DI TINJAU DARI PERATURAN PEMERINTAH PENGGANTI UNDANG- UNDANG NOMOR 1 TAHUN 2016 TENTANG PERLINDUNGAN ANAK
}

\author{
Endik Wahyudi ${ }^{1}$, Gerry Joe ${ }^{2}$ \\ ${ }^{1,2}$ Universitas Esa Unggul \\ 1endik.wahyudi@esaunggul.ac.id, ${ }^{2}$ gerry.joe@esaunggul.ac.id
}

\begin{abstract}
The crime of sexual violence in Indonesia is increasing every year. Criminal penalties for perpetrators of sexual violence as stated in the Penal Code and Child Protection Act were considered ineffective until the Government issued The Replacement Government Regulation No. 1 of 2016 that applies criminal sanctions to perpetrators of sexual violence among others by chemically applying castration. This is the background to conducting normative research on the policy of chemicalbirth sanction formulations that apply in Indonesia today. His arrangement of chemical castration and rehabilitation as an additional punishment, to date has not been published, so the mechanisms and technicalities are unknown. In addition, interested sectors are not involved in the establishment of such rules resulting in rejection as executors.
\end{abstract}

\section{Keywords :Formulation Policy, Chemical Castration Sanctions, Children.}

\begin{abstract}
ABSTRAK
Kejahatan kekerasan seksual di Indonesia mengalami peningkatan tiap tahunnya. Hukuman pidana bagi pelaku kekerasan seksual sebagaimana tercantum dalam KUHP dan Undang-Undang Perlindungan Anak dianggap belum efektif sehingga Pemerintah menerbitkan Peraturan Pemerintah Pengganti Undang-undang Nomor 1 Tahun 2016 yang menerapkan pemberatan sanksi pidana bagi pelaku kekerasan seksual diantaranya dengan memberlakukan kebiri secara kimiawi. Hal tersebut menjadi latar belakang melakukan penelitian secara normatif mengenai kebijakan formulasi sanksi kebiri kimia yang berlaku di Indonesia saat ini. Pengaturan tindakan kebiri kimia dan rehabilitasinya sebagai hukuman tambahan, hingga saat ini belum diterbitkan, sehingga mekanisme dan teknisnya tidak diketahui. Selain itu leading sector yang berkepentingan tidak dilibatkan dalam pembentukan aturan tersebut yang mengakibatkan penolakan sebagai eksekutor.
\end{abstract}

\section{Kata Kunci : Kebijakan Formulasi, Sanksi Kebiri Kimia, Anak.}

\section{PENDAHULUAN}

Kekerasan Seksual merupakan kejahatan serius yang semakin meningkat dari waktu ke waktu dan secara signifikan mengancam dan membahayakan jiwa, merusak kehidupan pribadi serta mengganggu rasa kenyamanan, ketentraman, keamanan, dan ketertiban masyarakat. Belakangan marak terjadi berbagai bentuk tindak pidana seksual yang sempat menjadi sorotan luar biasa yang menimpa anak- 
anak, atau perempuan diberbagai kota di Indonesia. Kasus Jakarta Internasional School adalah kasus pembuka tabir dari berbagai kasus kejahatan seksual yang pernah ada sebelumnya. Tercatat ada peningkatan kasus kekerasan seksual pada anak yang terjadi sejak 2016 sejumlah 25 kasus, lalu meningkat pada 2017 menjadi 81 kasus, dan puncaknya pada 2018 menjadi 206 kasus. ${ }^{1}$

Dengan ramainya pemberitaan tentang kekerasan seksual di Sekolah Jakarta Internasional School, membuat banyak masyarakat takut dan was-was terhadap kejahatan Seksual tersebut khususnya orang tua terhadap anak-anaknya. Masyarakat umum pun mendesak agar pelaku perbuatan tercela itu, mendapatkan hukuman yang berat atau setimpal dengan perlakuannya. Sebab, terjadinya kejadian tersebut dapat membuat korban-korban menjadi sakit dalam hal psikis atau trauma yang mendalam.

Undang-U²ndang Nomor 39 Tahun 1999 tentang Hak Asasi Manusia memuat pengakuan yang cukup luas terhadap hak asasi manusia. Undang-undang tersebut menjamin hak-hak sipil dan politik, hak-hak ekonomi, sosial dan budaya, sampai hak-hak kelompok seperti anak, perempuan dan masyarakat adat (indegenous people). Meskipun perlindungan anak telah diletakan dalam sebuah tataran perundang-undangan, tidak dapat dipungkiri bahwa tindakan kekerasan terhadap anak masih saja marak terjadi seperti: penelantaran, penyiksaan, diskriminasi, pencabulan, persetubuhan sampai pemerkosaan terhadap anak setiap hari menempati topik utama dalam pemberitaan disamping tindak korupsi dan narkotika. Penjatuhan hukuman pidana bagi pelaku tindakan-tindakan diatas telah diperberat namun tetap saja terulang kembali tindakan-tindakan negative tersebut terhadap anak. Sehingga efektifitas hukuman pidana kembali dipertanyakan.

Kasus pemerkosaan dan pembunuhan gadis cilik Y (14), warga Kabupaten Rejang Lebong, Bengkulu membuat prihatin rasa kemanusiaan. Hal itu membuat sejumlah elemen masyarakat beraksi keras dan meminta pemerintah bersikap tegas terhadap pelaku kejahatan seksual anak. Selain kasus Y ada 5 kasus pemerkosaan

\footnotetext{
1 News LPSK, "Kasus Kekerasan Seksual Pada Anak Meningkat Setiap Tahun," News.Detik.Com.

${ }^{2}$ Muhammad Lutfi Hardiyanto, Shalahudin Serba Bagus, Ahmad Munir, "Hak Politik Mantan Narapidana Untuk Mencalonkan Diri Sebagai Calon Kepala Daerah (Analisis terhadap Putusan MK. No. 42/PUU-XIII/2015)", Mimbar Yustitia, Vol. 1 No. 2, 2017, h. 112.
} 
dan pembunuhan terhadap anak di bawah umur sepanjang 2016. ${ }^{3}$ AH (22) ditangkap Prolres Kuantan singingi atas kasus pencabulan dan pembunuhan terhadap anak berumur 3,5 tahun pada 6 januari 2016. Tempat kejadian berada di kawasan perumahan Kebun Kelapa Sawit milik Sensui di Desa Sungai Pinang kecamatan Hulu Kuantan, Kabupaten Kuansing. ${ }^{4}$

Minggu, 24 januari 2016, Polsek talang Kelapa, Banyuasin, Sumatera Selatan Menangkap lima Orang tersangka atas kasus meninggalnya FF (13), siswi SMP di Palembang. Kelima tersangka kemudian dikenai pasal berlapis mulai dari pencurian dengan kekerasan, pembunuhan berencana dan pemerkosaan. ${ }^{5}$ Kakak diperkosa dan adiknya dibunuh di Pangkalpinang, pembunuhan berawal dari pelecehan seksual yang dilakukan F terhadap anak perempuannya FD (10) karena terpergok anaknya yang lain FI (5) pada 10 Februari 2016. Ia panik dan terjadilah pembunuhan tersebut. ${ }^{6}$ Bocah SD (10) di lampung ditemukan meninggal akibat kekerasan seksual. Di sebuah gubuk di tengah ladang di Kecamatan Jepara, Lampung Timur, ditemukan MS (10) dalam kondisi meninggal pada 17 April 2016. Hasil visum pada jasad korban ditemukan bekas dugaan tindak kekerasan seksual ${ }^{7}$. Hal yang hampir serupa juga dialami seorang balita, LN $(2,5)$ ditemukan tewas dengan kondisi mengenaskan di belakang rumah neneknya di Kampung Pabuarantonggoh, Desa Girimulya, Kecamatan Cibungbulang, Kabupaten Bogor, Senin 9 Mei 2016. Dari hasil visum ditemukan alat kelamin korban mengalami kerusakan dan terdapat tanda-tanda kekerasan di tubuh LN. Tidak berselang lama polisi berhasil meringkus tersangka, BD (26). ${ }^{8}$

Sebagai respon terhadap kasus tersebut, pemerintah menetapkan Peraturan Pemerintah Pengganti Undang-Undang (PERPU) Nomor 1 tahun 2016 tentang Perubahan kedua atas Undang-Undang Nomor 23 Tahun 2002 tentang Perlindungan Anak. Masalah menetapkan jenis sanksi dalam pidana tidak terlepas

\footnotetext{
${ }^{3}$ Septika Shidqiyyah, "5 Kasus Pemerkosaan Anak Di Bawah Umur Ini Bikin Geram Masyarakat!," Brilio.Net.

${ }^{4}$ Ibid.

${ }^{5}$ Defri Irawan, "Fikriyatul Diperkosa Beramai-Ramai Sebelum Dibuang Ke Kolam Bekas Galian," Tribunnews.Com.

${ }^{6}$ Ajie Gusti Prabowo, "Diva Yang Diperkosa Dan Dibunuh Bersama Adiknya Baru Kelas Ii Sd," Tribunnews.Com. Viva.Co.Id.

7 Priatmojo Dedy Ardian, "Sadis, Bocah Sd Di Lampung Diperkosa Lalu Dibunuh,"

8 Damanhuri, "Balita 2,5 Tahun Diperkosa Tetangganya Hingga Tewas Di Bogor," Tribunnews.Com.
} 
dari masalah penetapan tujuan yang ingin dicapai dalam pemidanaan. Dengan kata lain, perumusan tujuan pemidanaan diarahkan untuk dapat membedakan sekaligus mengarahkan sejauh mana kebijakan formulasi undang-undang tersbut dibuat, serta mengukur sejauh mana jenis sanksi, baik yang berupa pidana maupun tindakan yang telah ditetapkan itu dapat mencapai tujuan secara efektif. Berdasarkan uraian permasalah diatas maka yang menjadi pokok permasalahan yang dapat ditelaah oleh penulis dari penelitian ini adalah Bagaimana Kebijakan Formulasi Sanksi Pidana Kebiri Kimia di Indonesia Saat ini?

\section{METODELOGI}

Dalam Penulisan karya ilmiah ini, penulis menggunakan Jenis Penelitian Normatif. Penelitian normatif yaitu penelitian yang dilakukan dengan cara meneliti data sekunder. Penelitian hukum normatif mencangkup penelitian terhadap asasasas atau prinsip-prinsip hukum, sistematik hukum, taraf sinkronisasi vertical dan horizontal, perbandingan hukum dan sejarah hukum. Penelitian normative juga meneliti norma-norma hukum positif, asas-asas, prinsip-prinsip, dan doktrin-doktrin hukum. ${ }^{9}$ Lalu, Teknik pengumpulan data yang digunakan dalam penelitian ini adalah teknik penelitian kepustakaan (library research) dengan mengumpulkan bahan-bahan hukum tertulis yang relevan dengan masalah di dalam penelitian ini ${ }^{10}$, khususnya yang berkaitan dengan permasalahan. Bahan hukum yang diperoleh dengan menggunakan penelitian studi kepustakaan, aturan perundang-undangan, dan artikel, kemudian diuraikan dan dihubungkan sehingga dapat disajikan dalam penulisan yang lebih sistematis, guna menjawab permasalahan yang telah dirumuskan.

Data yang dikumpulan dalam penelitian ini berupa bahan hukum, yang terdiri dari bahan hukum primer, bahan hukum sekunder dan bahan hukum tersier. Bahan hukum primer, yaitu bahan-bahan hukum yang mempunyai kekuatan hukum mengikat. ${ }^{11}$ Pada skripsi ini bahan hukum primernya terdiri dari Undang Undang Nomor 17 Tahun 2016 tentang pengesahan Peraturan Pemerintah Pengganti

9 Johny Ibrahim, Teori Dan Metode Penelitian Hukum Normatif (Malang - Indonesia: Bayumedia Publishing, 2008).

${ }^{10}$ Mukti Fajar N.D And Yulianto Achmad, Dualisme Penelitian Hukum Normatif Dan Empiris (Yogyakarta - Indonesia: Pustaka Pelajar, 2010).

11 Soerjono Soekanto, Pengantar Penelitian Hukum, Jakarta - Indonesia: Universitas Indonesia (UI Press), 2007. 
Undang-undang Nomor 1 Tahun 2016 atas perubahan kedua atas Undang-Undang Nomor 23 Tahun 2002 tentang Perlindungan Anak, Kitab Undang-undang Hukum Pidana, serta Peraturan-peraturan yang relevan dengan permasalahan dan tujuan penelitian.Bahan Hukum Sekunder, yaitu terdiri dari bahan yang memberikan penjelasan mengenai bahan hukum primer. $^{12}$ Seperti buku-buku, skripsi-skripsi, surat kabar, artikel internet, hasil-hasil penelitian, pendapat para ahli atau sarjana hukum yang dapat mendukung pemecahan masalah yang diteliti dalam penelitian ini. Bahan Hukum Tersier, yaitu bahan-bahan yang memberi petunjuk terhadap bahan hukum primer dan bahan hukum sekunder, yang lebih dikenal dengan nama bahan acuan bidang hukum atau rujukan bidang hukum. ${ }^{13}$

\section{III.PEMBAHASAN}

\section{Kebijakan Formulasi Hukum Pidana dan Ruang Lingkupnya}

Istilah kebijakan diambil dari bahasa Inggris, yaitu "policy" atau yang dalam Bahasa Belanda adalah "Politiek". Dalam Black's Law Dictionary, policy diartikan sebagai prinsip-prinsip umum yang berfungsi untuk mengarahkan pemerintah (dalam arti luas termasuk pula aparat penegak hukum) dalam mengelola, mengatur, atau menyelesaikan urusan-urusan publik, masalah-masalah masyarakat atau bidang-bidang penyusunan peraturan perundang-undangan dan pengaplikasian hukum/peraturan, dengan suatu tujuan (umum) yang mengarah pada upaya mewujudkan kesejahteraan atau kemakmuran masyarakat (warga negara). ${ }^{14}$

Dalam Kamus Besar Bahasa Indonesia, istilah "Politik" diartikan sebagai berikut: ${ }^{15}$

1. Pengetahuan mengenai ketatanegaraan atau kenegaraan (seperti sistem pemerintahan, dasar-dasar pemerintahan);

2. Segala urusan dan tindakan (kebijakan, siasat dan sebagainya) mengenai pemerintahan negara atau terhadap negara lain;

3. Cara bertindak (dalam menghadapi atau menangani suatu masalah), kebijakan .

\footnotetext{
${ }^{12}$ Soekanto, Pengantar Penelitian Hukum.

${ }^{13}$ Abdulkadir Muhammad, Hukum dan Penelitian Hukum, Bandung - Indonesia: Citra Aditya Bakti, 2004.

${ }^{14}$ Henry Campbell, "Black's Law Dictionary," Black's Law, 1979.

15 Departemen Pendidikan Nasional, Kamus Besar Bahasa Indonesia, Edisi Kedu. (Jakarta Indonesia: Balai Pustaka, 1997).
} 
Robert R. Mayer dan Ernest Greenwood ${ }^{16}$, merumuskan kebijakan (policy) sebagai suatu keputusan yang menggariskan cara yang paling efektif dan paling efisien untuk mencapai tujuan yang ditetapkan secara kolektif. Sementara menurut Barda Nawawi Arief ${ }^{17}$, istilah "kebijakan" berasal dari kata "politic", "politics" dan "policy" (Inggris) atau "politiek" (Belanda). Politik berarti "acting of judging wisely, prudent", jadi ada unsur "wise" dan "prudent" yang berarti bijaksana. "Politics" berarti "the science of the art of government". Policy berarti a) Plan of action, suatu perencanaan untuk melakukan suatu tindakan dari negara, b) art of government, dan c) wise conduct.

Kebijakan hukum pidana mencakup pula pada kebijakan pembaharuan hukum pidana (penal reform). Pembaharuan hukum pidana pada hakikatnya mengandung makna, suatu upaya untuk melakukan reorientasi dan reformasi hukum pidana yang sesuai dengan nilai-nilai sentral sosio-politik, sosiofilosofik dan sosio-kultural masyarakat Indonesia yang melandasi kebijakan sosial, kebijakan kriminal dan kebijakan penegakan hukum di Indonesia. Secara singkat dapat dikatakan bahwa pembaharuan hukum pidana pada hakikatnya harus ditempuh dengan pendekatan yang berorientasi pada kebijakan (policy oriented approach) dan sekaligus pendekatan yang berorientasi pada nilai (value oriented approach). ${ }^{18}$ Pendekatan kebijakan dalam pembaharuan hukum pidana tersebut meliputi:

a. Sebagai bagian dari kebijakan sosial, pembaharuan hukum pidana pada hakikatnya merupakan bagian dari upaya untuk mengatasi masalahmasalah sosial (termasuk masalah kemanusiaan) dalam rangka mencapai/menunjang tujuan nasional (kesejahteraan masyarakat dan sebagainya);

b. Sebagai bagian dari kebijakan kriminal, pembaharuan hukum pidana pada hakikatnya merupakan bagian dari upaya perlindungan masyarakat (khususnya upaya penanggulangan kejahatan);

c. Sebagai bagian dari kebijakan penegakan hukum, pembaharuan hukum pidana pada hakekatnya merupakan bagian dari upaya memperbaharui substansi hukum (legal substance) dalam rangka lebih mengefektifkan penegakan hukum.

\footnotetext{
${ }^{16}$ Zanti Arbi Sutan And Ardhana Wayan, Rancangan Penelitian Kebijakan Sosial (Jakarta Indonesia: Pustekkom Dikbud Dan Cv Rajawali, 1984).

${ }^{17}$ Barda Nawawi Arief, Kebijakan Kriminal (Criminal Policy) (Bandung - Indonesia: Fh Universitas Katolik Parahyangan, 2013).

${ }^{18}$ Barda Nawawi Arief, Bunga Rampai Kebijakan Hukum Pidana (Bandung - Indonesia: Fh Universitas Katolik Parahyangan, 2013).
} 
Sementara pembaharuan hukum pidana dilihat dari sudut pendekatan nilai pada hakekatnya merupakan upaya melakukan peninjauan dan penilaian kembali ("reorientasi dan reevaluasi") nilai-nilai sosio politik, sosio filosofik dan sosio kultural yang melandasi dan memberi isi terhadap muatan normatif dan substantif hukum pidana yang dicita-citakan. ${ }^{19}$

Ruang lingkup "penal reform" adalah dalam "penal system reform" yang meliputi:

1. Pembaharuan substansi hukum pidana (pembaharuan substansial)

2. Pembaharuan struktural hukum pidana (pembaharuan struktural)

3. Pembaharuan budaya hukum pidana (pembaharuan kultural).

Konsep KUHP merupakan bagian dari pembaharuan substansial yang tentunya harus didukung pula dengan pembaharuan struktural dan pembaharuan kultural, sehingga penegakan hukum dapat berjalan dengan maksimal.

Salah satu sarana dalam upaya penanggulangan kejahatan adalah sarana penal (hukum pidana), yaitu melalui kebijakan hukum pidana atau disebut pula dengan istilah politik hukum pidana. Ada beberapa istilah asing yang digunakan terhadap istilah politik hukum pidana, antara lain penal policy, criminal law policy atau strafrechtspolitiek.

Pengertian kebijakan hukum pidana dapat dilihat dari politik hukum maupun dari politik kriminal. Menurut Sudarto, politik hukum pidana adalah :

1. Mengadakan pemilihan untuk mencapai hasil perundang-undangan pidana yang paling baik dalam arti memenuhi syarat keadilan dan daya guna. $^{20}$

2. Usaha mewujudkan peraturan perundang-undangan pidana yang sesuai dengan keadaan dan situasi pada suatu waktu dan untuk masa-masa yang akan datang. ${ }^{21}$

Sementara menurut Marc Ancel, penal policy adalah suatu ilmu sekaligus seni yang bertujuan untuk memungkinkan peraturan hukum positif dirumuskan secara lebih baik. Berdasarkan 2 (dua) pengertian di atas, pada dasarnya kebijakan

\footnotetext{
${ }^{19}$ Ibid.

${ }^{20}$ Sudarto, Hukum Dan Hukum Pidana (Bandung - Indonesia: Alumni, 1977).

${ }^{21}$ Sudarto, Hukum Pidana Dan Perkembangan Masyarakat "Kajian Terhadap Pembaharuan Hukum Pidana” (Bandung - Indonesia: Sinar Baru, 1983).
} 
hukum pidana merupakan upaya untuk merumuskan suatu undang-undang yang lebih baik dalam rangka penanggulangan kejahatan yang lebih efektif.

Kebijakan Sanksi Kebiri Kimia Bagi Pelaku Pedofilia Dalam Hukum Positif Indonesia

Kebiri dalam pengertian Kamus Bahasa Indonesia kontemporer, ialah memiliki arti sudah dihilangkan atau sudah dikeluarkan (kelenjar testisnya pada hewan jantan) atau (dipotong ovariumnya pada hewan betina), atau dengan kata lain telah dimandulkan. ${ }^{22}$ Pada dasarnya, ada dua macam teknik kebiri, yaitu kebiri fisik dan kebiri kimiawi. Kebiri fisik dilakukan dengan cara mengamputasi organ seks eksternal pemerkosa, sehingga membuat pelaku kekurangan hormon testosteron. Kurangnya hormon ini akan banyak mengurangi dorongan seksualnya. Sementara itu, kebiri kimiawi dilakukan dengan cara memasukkan zat kimia antiandrogen ke tubuh seseorang supaya produksi hormon testosteron di tubuh mereka berkurang. Hasil akhirnya sama dengan kebiri fisik. ${ }^{23}$

Praktik pengebirian sudah dilakukan manusia bahkan jauh sebelum tercatat dalam sejarah. Kebiri kadang kala dilakukan atas dasar alasan keagaman atau sisial bida tertentu di Eropa, Timur Tengah, Asia Selatan, Afrika dan Asia Timur. Setelah peperangan, pemenang biasanya mengebiri dengan memotong penis dan testis mayat prajurit yang telah dikalahkan sebagai tindakan simbolis "merampas" kekuatan dan keperkasaan mereka.

Laki-laki yang dikebiri biasanya dipekerjakan dan diterima pada kelas sosial istimewa dan biasanya menjadi pegawai birokasi atau rumah tangga istana, khususnya harem. Dalam sejarah Tiongkok, orang kasim atau disebut sida-sida diketahui memegang kekuasaan yang cukup besar di istana, terkadang merebut kekuasaan dari kaisar yang sah, seperti disebutkan dalam sejarah dinasti Han, dan masa menjelang akhir dinasti Ming. Peristiwa yang sama juga dilaporkan terjadi di Timur Tengah.

Pada masa purba, pengebirian juga melibatkan pemotongan seluruh alat kelamin pria, baik testis sekaligus penis. Praktik ini sangat berbahaya dan kerap

\footnotetext{
${ }^{22}$ Salim Peter And Salim Yenny, Kamus Bahasa Indonesia Kontemporer, Edisi Pert. (Jakarta - Indonesia: Modern English Press, 1991).

${ }^{23}$ Kumala Dewi Bestari, Efek Hukuman Kebiri Kimiawi Pada Tubuh (Jakarta - Indonesia: Kompas.Com, 2017).
} 
mengakibatkan kematian akibat pendaharan hebat atau infeksi, sehingga dalam beberapa kebudayaan seperti Kekaisaran Byzantium, pengebirian disamakan dengan hukuman mati. Pemotongan hanya testisnya saja mengurangi risiko kematian.

Pembedahan untuk mengangkat kedua testis atau pengebirian secara kimia secara medis mungkin dilakukan sebagai prosedur pengobatan kanker prostat. Pengobatan dengan mengurangi atau menghilangkan asupan hormone testoteron baik secara kimia ataupun bedah dilakukan untuk memperlambat perkembangan kanker. Hilangnya testis yang berarti hilangnya pula hormone testoteron mengurangi hasrat seksual, obsesi, dan perilaku seksual. ${ }^{24}$

Ada dua macam kebiri yang diterapkan di berbagai Negara, yaitu kebiri fisik dan kebiri kimia. Kebiri Fisik dilakukan dengan cara mengamputasi testis pelaku pedofil sehingga membuat pelaku kekurangan hormone testoteron yang mempengaruhi dorongan seksualnya. Sementara itu kebiri kimiawi, berbeda dengan kebiri fisik, tidak dilakukan dengan memotong tektis. Kebiri kimiawi dilakukan dengan cara memasukan (melalui pil) atau menyuntikan bahan kimia atau cairan kimia antiadrogen, ketubuh seseorang dengan tujuan memperlemah hormone testoteron. Secara sederhana, zat kimia dimasukan kedakam tubuh itu akan mengurangi bahkan menghilangkan kemampuan ereksi, libido atau hasrat seksual.

Pengebirian bagi pelaku kekerasan seksual bukan merupakan jenis sanksi baru dalam hukum pidana, namun sepanjang sejarah sudah banyak dipraktikan oleh Negara-negara didunia, dan masih banyak digunakan sampai akhir Perang Dunia Kedua. Saat itu bentuknya berupa kebiri melalui bedah atau fisik (surgical cascration). Kebiri sudah dijadikan pidana di mesir kuno untuk pelaku perzinahan, kemudian diterapkan di Eropa Barat pada abad ke -12 untuk pelaku pemerkosaan, dan diterapkan di Prancis pada abad ke-13 untuk pelaku homoseksual ${ }^{25}$. Karena prosedurnya yang dianggap rumit, maka banyak Negara-negara yang tidak lagi menerapkan kebiri. Baru pada tahun 1970-an, mulai dikembangkan obat yang dapat mengurangi jumlah hormone testoteron pada pria atau yang kemudian dikenal dengan kebiri kimia (chemical castration). Hanya saja penggunaan kebiri kimia

\footnotetext{
${ }^{24}$ Wikipedia, "Kebiri," Wikipedia.

${ }^{25}$ Stojanovksi Vioslav, "Surgical Castration Of Sex Offenders And Its Legality: The Case Of The Czech Republic,” Theoretical Legal Sciences Iv, No. Departemen Of Criminal Law (N.D.): 4.
} 
berupa suntik antiandrogen, diketahui mempunyai dampak negatif yaitu mempercepat penuaan tubuh. Cairan antiandrogen yang disuntikan kedalam tubuh mengurangi kerapatan masa tulang sehingga tulang keropos dan memperbesar risiko patah tulang. Obat itu juga mengurangi masa otot dan meningkatkan lemak yang menaikan risiko penyakit jantung dan pembuluh darah. Jika pemberian antiandrogen dihentikan, dorongan seksual dan fungsi ekesi seseorang akan muncul lagi. $^{26}$

\section{Tentang Pedofilia\& Karakteristik Pedofilia}

Pedofilia adalah kelainan seksual berupa hasrat ataupun fantasi impuls seksual yang melibatkan anak di bawah umur. Orang dengan pedofilia umurnya harus di atas 16 tahun, sedangkan anak-anak yang menjadi korban berumur 13 tahun atau lebih muda (anak pra-pubertas). ${ }^{27}$ Sehingga dari uraian diatas, Pedofilia adalah ketertarikan seksual orang dewasa terhadap anak-anak, anak-anak yang menjadi sasaran dari pemuasan birahi seksual orang dewasa pengidap pedofilia ini adalah anak-anak pra-pubertas atau anak-anak yang belum mengalami pubertas, penyebab dari munculnya penyakit ketertarikan seksual ini bisa disebabkan pertama oleh pengalaman masa kecilnya yang tidak mendukung perkembangan kedewasaannya dan kedua bisa juga karena trauma pernah mendapatkan kekerasan seksual dari orang dewasa.

Pedofilia adalah salah satu bentuk penyakit jiwa kelainan ketertarikan seksual. Untuk melampiaskan nafsu birahinya seorang pedofil akan mencari anak yang belum matang dan siap baik reproduksi seksualnya, tujuannya adalah agar pedofil bisa menguasai dan memaksakan penisnya di penetrasikan kedalam dubur, liang vagina atau oral seks sehingga korban akan merasa sakit yang amat sangat. Rasa sakit inilah yang diharapkan oleh pelaku dialami oleh korban, dengan erangan rasa sakit si pedofil akan semakin terangsang. ${ }^{28}$

Erich Formm mengidentifikasi pedofilia adalah penyakit penyimpangan seksual yang masuk dalam kategori sadisme, dengan perilaku sadis pada saat itulah pelaku merasa berkuasa terhadap korbannya dan semakin korban merasa sakit

\footnotetext{
${ }^{26}$ Berita Tagar, "Apa Dan Bagaimana Kebiri Kimiawi Bagi Pedofilia,” Beritatagar.Id.

${ }^{27}$ Scribd.Com, "Definisi Pedofilia," Scribd.Com.

${ }^{28}$ Dwi Yuwono Ismantoro, Penerapan Hukum Dalam Kasus Kekerasan Seksual Terhadap Anak (Jakarta - Indonesia: Pustaka Yustisia, 2015).
} 
ketika disodomi atau disetubuh maka semakin merasa berkuasa. Kemunculan pedofilia disebabkan oleh dua hal, pertama pada masa pertumbuhannya seorang pedofil telah terperangkap dalam berbagai kondisi yang membuatnya merasa kesepian dan tidak berdaya. Bersamaan dengan ini anak pada masa kecilnya selalu mendapatkan kekerasan dari orang dewasa dan tindakan orang dewasa yang membuat anak ketakutan, misalnya selalu diancam akan dihukum jika tidak mau melakukan ini itu, pada saat itu anak merasa harga diri nya hancur dan dibawah orang dewasa. Yang kedua anak pada masa kecilnya merasa mengalami kehampaan jiwa. Tidak ada stimulasi, tidak ada yang akan dapat membangkitkan kecakapan dan potensinya.

Gabungan dari kedua faktor itulah yang kemudian menggiring anak mengembangkan ketertarikan menguasai dan menyakiti orang lain sebagai bentuk perlawanan atas kondisi yang tidak kondusif dalam menumbuhkan kedewasaan, ada percampuran antara rasa takut terhadap orang dewasa, rasa benci dan jijik dan adapula dorongan rasa mencari kompensasi yang ditemukan pada sosok anak-anak yang bisa dikuasainya.

Anak yang menjadi korban kejahatan pedofilia akan terkondisikan atau mengalami dampak negatif sebagai berikut: ${ }^{29}$ :

1. Muncul trauma fisik dari diri sianak, taruma ini muncul karena rasa sakit yang amat sangat ketika pelaku melakukan penetrasi, taruma ini akan semakin mendalam dialami oleh anak apabila rasa sakit pasca penetrasi diikuti oleh infeksi atau tertular penyakit kelamin.

2. Muncul trauma psikis pada diri si anak, yang disebabkan oleh norma-norma sosial yang ditamankan pada diri si anak oleh lingkungan keluarga dan sosialnya. Semakin tertanam norma-norma sosial tersebut kedalam diri anak maka akan semakin traumalah si anak. Trauma psikis ini biasanya ditampakkan oleh si anak melalui perubahan perilaku yang aneh yang belum pernah ditampilkan oleh sianak sebelum menjadi korban pedofilia, misalnya si anak menjadi paranoid, gelisa, pelupa, dan sering mengalami kebingungan.yang akan membuat anak menjadi pendiam karena selalu dihantui rasa ternoda karena telah melakukan perbuatan tidak senonoh.

3. Muncul disorientasi moral pada diri si anak karena disebabkan oleh seringnya korban mengalami kekerasan seksual sehingga anak tidak bisa membedakan mana perilaku seksual yang baik dan mana yang tidak. Ketika anak berada pada kondisi atau terkondisikan dalam disorientasi moral inilah dikemudian hari anak tumbuh menjadi dewasa dan akan memiliki potensi menjadi penjahat pedofilia.

\footnotetext{
${ }^{29}$ Ibid.
} 
Ciri seseorang mengalami pedofilia antara $\operatorname{lain}^{30}$ :

1. Memiliki latar belakang pelecehan seksual

Walaupun korban kekerasan seksual tidak menjadi pelaku di kemudian hari, tetapi penelitian membuktikan bahwa pelaku pedifilia pernah mengalami kekerasan seksual sebelumnya. Reza Indragiri Amriel, ahli psikologi forensik dari Universitas Bina Nusantara mengatakan bahwa 4 dari lima pelaku pedofilia pernah mengalami kekerasan seksual pada masa kanak kanak.

2. Memiliki kontak sosial yang terbatas pasa masa remaja.

Preferensi seorang pedofil dimulai pada saat usia remaja. Dengan demikian, pelaku biasanya tidak memiliki ketertarikan sosial terhadap teman seumuran mereka

3. Memiliki banyak korban sebelumnya.

Jika penyelidikan menyatakan bahwa individu telah mencabul banyak korban yang berlainan, maka kemungkinan seseorang tersebut adalah pedofilia. Sebagai contoh, bila seorang guru mencabuli salah satu muridnya, kemungkinan besar murid lainnya akan menjadi korban.

4. Mengoleksi foto pornografi tentang anak.

Seorang pedofil menggunakan koleksi tersebut untuk membangkitkan gairah seksualnya. Mereka juga dapat bertukar koleksi dengan pedofil lain.

\section{Analisis Pengaturan Perlindungan anak}

Undang-undang Nomor 23 Tahun 2002 tentang Perlindungan Anak menegaskan bahwa pertanggungjawaban orang tua, keluarga, masyarakat, pemerintah, dan Negara merupakan rangkaian kegiatan yang dilaksanakan secara terus menerus demi terlindunginya anak. Rangkaian kegiatan tersebut harus berkelanjutan dan terarah guna menjamin pertumbuhan dan perkembangan anak, baik fisik, mental, spiritual, maupun sosial. Tindakan ini dimaksudkan untuk mewujudkan kehidupan terbaik bagi anak yang diharapkan sebagai penerus bangsa yang potensial, dan tangguh.

Oleh karena itu, dalam undang-undang perlindungan Anak juga dijelaskan ketentuan umum perlindungan anak pada Pasal 1 butir 2, yang menyatakan bahwa perlindungan anak adalah segala kegiatan untuk menjamin dan melindungi anak dan hak-hak yang agar dapat hidup, tumbuh, berkembang dan berpartisipasi, secara optimal sesuai dengan harkat dan martabat kemanusiaan, serta mendapat perlindungan dari kekerasan dan diskriminasi.

Upaya perlindungan terhadap anak perlu dilaksanakan sedini mungkin, yakni sejak dari janin dalam kandungan sampai anak berumur 18 (delapan belas)

\footnotetext{
${ }^{30}$ Mywapblog, “Karakteristik Dan Ciri-Ciri Pedofilia,” Xiotwo.Mywapblog.Com.
} 
tahun. Hal ini bertitik tolak dari konsepsi perlindungan anak yang utuh, menyeluruh dan komprehensif. Undang-undang perlindungan anak juga harus meletakan kewajiban memberikan perlindungan anak berdasarkan asas-asas nondiskriminatif, kepentingan yang terbaik bagi anak, hak untuk hidup, kelangsungan hidup, dan perkembangan, serta penghargaan terhadap pendapat anak.

Undang-undang Perlindungan Anak nomor 23 Tahun 2002 diundangkan pada tanggal 22 Oktober 2002 Undang-undang yang terdiri dari 14 Bab dan 93 pasal ini, di lakukan perubahan dengan Undang-undang Nomor 35 Tahun 2014 yang di undangkan pada tanggal 17 Oktober 2014. Kemudian dua tahun berselang, dilakukannya kembali perubahan kedua atas Undang-undang Perlindungan Anak melalui Peraturan Pemerintah Pengganti Undang-undang Nomor 1 Tahun 2016 yang ditetapkan menjadi undang-undang nomor 17 pada tanggal 9 November 2016. Menurut penulis perlu dianalisis berkaitan dengan upaya perlindungan anak terhadap kekerasan atau kejahatan seksual, karena maraknya pemberitaan mengenai Pedofilia di media baik televisi, internet maupun media cetak.

Adapun pengertian perlindungan anak yang diatur dalam Ketentuan Umum Pasal 1 angka 2 adalah sebagai berikut bahwa "Perlindungan anak adalah segala kegiatan untuk menjamin dan melindungi anak dan hak-haknya agar dapat hidup, tumbuh berkembang, dan berpartisipasi secara optimal sesuai dengan harkat dan martabat kemanusiaan, serta mendapat perlindungan dari kekerasan dan diskriminasi”. Sementara pengertian Kekerasan sebagaimana diatur dalam Pasal 1 angka 15a adalah sebagai berikut: "Kekerasan adalah setiap perbuatan terhadap anak yang berakibat timbulnya kesengsaraan atau penderitaan secara fisik, psikis, seksual, dan/atau penelantaran, termasuk amcaman untuk melakukan perbuatan, pemaksaan atau perampasan kemerdekaan secara hukum”.

\section{Sistem Perumusan Tindak Pidana Dalam Undang-undang Perlindungan Anak} nomor 23 Tahun 2002

Ketentuan pidana dalam Undang-undang Nomor 23 tahun 2002 tentang Perlindungan anak diatur dalam Bab XII, mulai Pasal 77 sampai dengan Pasal 90. Namun dalam hal pengaturan yang kaitannya dengan seksual, terdapat pada Pasal 78, Pasal 81, Pasal 82, Pasal 88 dan Pasal 90. Dalam Undang-undang Perlindungan 
Anak ini tidak diatur secara tegas tentang kualifikasi delik, namun dapat kita lihat secara implisit dari ancaman pidananya :

1. Tindak pidana sebagaimana dimaksud dalam Pasal 78 (jo. Pasal 59 dan 60) adalah pelanggaran. Terlihat dari ancaman pidana maksimal 5 Tahun Penjara dan/atau denda maksimal Rp. 100.000.000,- (seratus juta rupiah).

2. Tindak pidana sebagaimana dimaksud dalam Pasal 81, Pasal 82 dan Pasal 88 adalah Kejahatan. Terlihat dari ancaman pidana minimal 3 tahun hingga maksimal 15 tahun penjara dan denda paling sedikit Rp. 60.000.000,- (enam puluh juta rupiah).

Berdasarkan ketentuan pidana di atas, maka dapat diidentifikasikan unsurunsur tindak pidana pada setiap pasalnya, yaitu:

1. Pasal 78 jo Pasal 59 dan Pasal 60 : mengetahui dan sengaja membiarkan anak dalam situasi darurat (anak pengungsi, korban kerusuhan, bencana alam, situasi konflik bencana), anak yang berhadapan dengan hukum, anak dari kelompok minoritas dan terisolasi, anak yang tereksploitasi secara ekonomi dan/atau seksual, anak yang diperdagangkan, anak yang menjadi korban penyalahgunaan narkotika, alkohol, psikotropika, dan zat adiktif lainnya (napza), anak korban penculikan, anak korban perdagangan, atau anak korban kekerasan padahal anak tersebut memerlukan pertolongan dan harus dibantu.

2. Pasal 81 ayat 1 : Dengan sengaja melakukan kekerasan atau ancam kekerasan memaksa anak melakukan persetubuhan dengannya atau dengan orang lain.

3. Pasal 81 ayat 2 : dengan sengaja melakukan tipu muslihat, serangkaian kebohongan, atau membujuk anak melakukan persetubuhan dengannya atau dengan orang lain.

4. Pasal 82 : dengan sengaja melakukan kekerasan atau ancaman kekerasan, memaksa, melakukan tipu muslihat, serangkaian kebohongan, atau membujuk anak untuk melakukan atau membiarkan dilakukan perbuatan cabul.

5. Pasal 88 : mengeksploitasi ekonomi atau seksual anak dengan maksud untuk menguntungkan diri sendiri atau orang lain.

6. Pasal 90 : Perbuatan yang melanggar ketentuan pidana dalam undang-undang perlindungan anak, namun dilakukan oleh korporasi. 
Rumusan ketentuan pidana dalam undang-undang perlindungan anak di atas tidak menyebutkan secara tegas adanya unsur "...sifat melawan hukum..”. Namun pada dasarnya unsur tersebut terkandung dalam perumusan “... sebagaimana dimaksud dalam pasal...". Selain itu, pada prinsipnya setiap delik tentunya harus dianggap bertentangan dengan hukum. Sementara rumusan “...dengan sengaja...” atau “...sengaja membiarkan..." dicantumkan secara tegas, sehingga jelas ada unsur kesengajaan (dolus) yang berarti menganut asas kesalahan atau asas culpabilitas.

Ketentuan pidana perihal kejahatan seksual dalam Undang-undang Perlindungan Anak di atas apabila dicermati terfokus pada perorangan yang melakukan pemaksaan, ancaman, tipu muslihat, atau kebohongan agar anak melakukan persetubuhan atau perbuatan cabul, baik untuk menguntungkan diri sendiri maupun orang lain. Namun dalam perumusan tindak pidananya menurut penulis ada beberapa kekurangan dan kelemahan, yaitu:

1. Ketentuan Pasal 81 dan 82 pemberian minimal hukuman hanya 3 Tahun merupakan hukuman yang ringan. Apalagi bila kita melihat dari sisi korban, perbuatan tersebut dapat menyebabkan trauma psikis dan kerugian yang disebabkan perbuatan tersebut.

2. Ketentuan pasal 81 dan pasal 82 tersebut juga tidak memberikan tambahan pemberatan bagi korban seksual dalam hal ini adalah anak yang menjadi korban, yang bisa saja mendapatkan luka fisik seperti rusaknya fungsi organ kelamin atau terpaparnya penyakit kelamin menular.

3. Ketentuan pasal 90 hanya memberikan saksi berupa denda tidak memberikan efek yang jera kepada korporasi atau badan hukum yang melanggar aturan tersebut. Padahal bisa saja diberikan pilihan atau alternatif pidana berupa sanksi administratif bagi korporasi atau badan hukum.

\section{Sistem Perumusan Tindak Pidana Dalam Undang-undang Perlindungan Anak Nomor 35 Tahun 2014}

Perubahan ketentuan pidana dalam Undang-undang Nomor 35 tahun 2014 tentang Perlindungan anak, yaitu perubahan pada Pasal 77, penambahan Pasal 77A dan 77B, perubahan Pasal 80, pasal 82, pasal 83, Pasal 87, Pasal 88, dan Pasal 89. Namun dalam hal pengaturan yang kaitannya dengan seksual, terdapat perubahan 
pada Pasal 81, Pasal 82, dan Pasal 88. Dalam Undang-undang Perlindungan anak ini, perubahan yang dilakukan sepenuhnya secara tegas tentang kualifikasi delik kejahatan, yang dapat kita lihat secara eksplisit dari kalimat “... melanggar ketentuan sebagaimana dimaksud dalam pasal..." yang dapat diidentifikasikan unsur-unsur tindak pidana pada setiap pasalnya, yaitu:

1. Pasal 81 ayat 1 jo Pasal 76D : Dilarang melakukan Kekerasan atau ancaman Kekerasan memaksa Anak melakukan persetubuhan dengannya atau dengan orang lain.

2. Pasal 81 ayat 2 jo Pasal 81 ayat 1 : Dilarang dengan sengaja melakukan tipu muslihat, serangkaian kebohongan, atau membujuk Anak melakukan persetubuhan dengannya atau dengan orang lain.

3. Pasal 81 ayat 3 jo Pasal 81 ayat 1 : Penambahan 1/3 ancaman pidananya pada pemenuhan unsur pidana yang dilakukan oleh orang tua, wali, pengasuh anak, pendidik atau tenaga kependidikan.

4. Pasal 82 ayat 1 jo Pasal 76E : Dilarang melakukan Kekerasan atau ancaman Kekerasan, memaksa, melakukan tipu muslihat, melakukan serangkaian kebohongan, atau membujuk Anak untuk melakukan atau membiarkan dilakukan perbuatan cabul.

5. Pasal 82 ayat 2 jo Pasal 81 ayat 1 : Penambahan $1 / 3$ ancaman pidananya pada pemenuhan unsur pidana yang dilakukan oleh orang tua, wali, pengasuh anak, pendidik atau tenaga kependidikan.

6. Pasal 88 jo Pasal 76I : Setiap Orang dilarang menempatkan, membiarkan, melakukan, menyuruh melakukan, atau turut serta melakukan eksploitasi secara ekonomi dan/atau seksual terhadap Anak.

Perubahan ketentuan pidana perigak kejahatan seksual dalam undangundang perlindungan anak nomor 35 tahun 2014 diatas apabila dicermati, hanya dilakukan pemisahan kesalahan atau kejahatan yang tidak dilakukan pada undangundang perlindungan anak sebelumnya. Terlihat dengan disisipkannya Pasal 76A hingga Pasal 76J yang merupakan pengembangan dan pemisahan Pasal 76 dan dilakukanya penambahan pidana pemberatan $1 / 3$ dari ancaman pidananya apabila pidana tersebut dilakukan oleh orang tua, wali, pengasuh anak, pendidik atau tenaga kependidikan. 


\section{Sistem Perumusan Tindak Pidana Dalam PERPU Nomor 1 Tahun 2016}

Perubahan ketentuan pidana dalam Peraturan Pemerintah Pengganti Undang-undang Nomor 1 tahun 2016 tentang Perlindungan Anak, yaitu perubahan dalam hal pengaturan yang kaitannya dengan seksual, terdapat perubahan pada Pasal 81 dan Pasal 82, serta ditambahkannya pasal 81A dan Pasal 82A.

Ketentuan pidana perihal kejahatan seksual dalam Peraturan Pemerintah Pengganti Undang-undang Nomor 1 Tahun 2016 tentang Perlindungan Anak di atas apabila dicermati terfokus pada perorangan yang melakukan pemaksaan atau dengan paksaan persetubuhan dan/atau dengan tipu muslihat. Namun dalam perumusan tindak pidananya menurut penulis ada beberapa kekurangan dan kelemahan, yaitu :

1. Ketentuan Pasal 81 ayat 7 jo Pasal 81 A ayat 4, perihal Peraturan Pemerintah tentang pelaksanaan teknis dan mekanisme tindakan kebiri kimia dan rehabilitasi yang hingga saat ini (empat tahun setelah Peraturan Pemerintah Pengganti Undang-undang tersebut di undangkan) belum juga di terbitkan.

2. Tidak adanya perubahan Ketentuan pasal 90 yang hanya memberikan saksi berupa denda tidak memberikan efek yang jera kepada korporasi atau badan hukum yang melanggar aturan tersebut. Padahal bisa saja diberikan pilihan atau alternatif pidana berupa sanksi administratif bagi korporasi atau badan hukum.

\section{Sistem Perumusan Pertanggungjawaban Pidana dalam Undang-undang Perlindungan Anak}

Pertanggungjawaban pidana erat hubungannya dengan subjek Tindak pidana. Dalam undang-undang perlindungan anak ini, pidana dapat diajtuhkan kepada indovidu, hal ini terlihat deri subjek hukum pidana yang terkandung dalam ketentuan pidananya, yaitu dalam rumusan "Setiap Orang...". Delik-delik Perlindungan Anak dapat dikenakan kepada korporasi, namun Undang-undang Perlindungan anak tidak mengatur lebih lanjut dan terperinci tentang ketentuan pertanggungjawaban pidananya. Pengaturan subjek hukum korporasi hanya tercantum satu pasal yaitu pada Pasal 90 Undang-undang Perlindungan Anak No 23 tahun 2002. Akibatnya tidak ada perbedaan sistem pertanggungjawaban pidana dan aturan pemidanaan antara individu dengan korporasi. Padahal ada perbedaan 
prinsip antara individu dengan korporasi. Oleh karena itu perumusan korporasi sebagai subjek tindak pidana hendaknya disertai dengan ketentuan pertanggungjawaban dan pedoman pemidanaannya yang berbeda dengan subjek tindak pidana individu. Misalnya mengatur tentang kapan dan siapa yang dapat dipertanggungjawabkan serta bagaimana jenis dan ancaman pidananya (selain pidana denda).

\section{Kesimpulan}

Kebijakan Hukum pidana saat ini dalam upaya perlindungan anak terkait kejahatan seksual termuat dalam Undang-undang Nomor 17 Tahun 2016 tentang pengesahan Peraturan Pengganti Undang-undang Nomor 1 Tahun 2016 tentang perubahan kedua atas Undang-undang Nomor 35 Tahun 2014 tentang perubahan pertama atas Undang-undang Nomor 23 Tahun 2002 tentang Perlindungan Anak. Namun pada tahap aplikasi, beberapa kebijakan ini tidak dapat bekerja dengan maksimal karena mengandung beberapa kelemahan dan kekurangan pada substansi pengaturannya diantaranya yakni sistem perumusan pertanggungjawaban pidana korporasi yang tidak jelas dan rinci, tidak diaturnya pedoman dan aturan pemidanaan, dan tidak adanya harmonisasi substansi tindak pidana dan tujuan dan pemidanaan itu sendiri, pengaturan tindakan kebiri kimia dan rehabilitasinya sebagai hukuman tambahan, hingga saat ini belum diterbitkan, sehingga mekanisme dan teknisnya tidak diketahui. Selain itu leading sector yang berkepentingan tidak dilibatkan dalam pembentukan aturan tersebut yang mengakibatkan penolakan sebagai eksekutor, dan Ikatan Dokter Indonesia melakukan penolakan dengan dasar pelanggaran atau bertolak belakang dengan hukum kesehatan yang berlaku di Indonesia dengan menyatakan kebiri kimia merupakan penghilangan fungsi organ dan bukan mengobati.

\section{V.Saran}

Kepada para pembuatan kebijakan formulasi pidana untuk sesegera mungkin mengeluarkan Peraturan Pemerintah terkait pelaksanaan teknis dan mekanisme Tindakan kebiri kimia dan Rehabilitasinya yang terdapat pada Pasal 81A ayat 4 Peraturan Pemerintah Pengganti Undang-Undang Nomor 1 Tahun 2016. Sebab sejak diterbitkannya peraturan tersebut telah ada dua putusan yang menyatakan Kebiri Kimia sebagai tindakan tambahan setelah pidana pokok. 


\section{DAFTAR BACAAN}

Ardian, Priatmojo Dedy. "Sadis, Bocah SD Di Lampung Diperkosa Lalu Dibunuh." Viva.Co.Id.

Berita Tagar. "Apa Dan Bagaimana Kebiri Kimiawi Bagi Pedofilia." Beritatagar.Id.

Bestari, Kumala Dewi. Efek Hukuman Kebiri Kimiawi Pada Tubuh. Jakarta Indonesia: Kompas.com, 2017.

Campbell, Henry. “Black’s Law Dictionary.” Black's Law, 1979.

Damanhuri. "Balita 2,5 Tahun Diperkosa Tetangganya Hingga Tewas Di Bogor." Tribunnews.Com.

Departemen Pendidikan Nasional. Kamus Besar Bahasa Indonesia. Edisi Kedu. Jakarta - Indonesia: Balai Pustaka, 1997.

Fuat Usfa, A, and Tongat. Pengantar Hukum Pidana. Malang - Indonesia: UMM Press, 2004.

Hardiyanto, Muhammad Lutfi, Shalahudin Serba Bagus, Ahmad Munir, "Hak Politik Mantan Narapidana Untuk Mencalonkan Diri Sebagai Calon Kepala Daerah (Analisis terhadap Putusan MK. No. 42/PUU-XIII/2015)", Mimbar Yustitia, Vol. 1 No. 2, 2017.

Ibrahim, Johny. Teori Dan Metode Penelitian Hukum Normatif. Malang Indonesia: Bayumedia Publishing, 2008.

Irawan, Defri. "Fikriyatul Diperkosa Beramai-Ramai Sebelum Dibuang Ke Kolam Bekas Galian.” Tribunnews.Com.

Ismantoro, Dwi Yuwono. Penerapan Hukum Dalam Kasus Kekerasan Seksual Terhadap Anak. Jakarta - Indonesia: Pustaka Yustisia, 2015.

Mahmud, Mulyadi. Bahan Kuliah Pembaharuan Hukum Pidana. Sumatera Utara Indonesia: Universitas Sumatera Utara, 2002.

Marlina. Hukum Penitesier. Bandung - Indonesia: Refika Aditama, 2011.

Muhammad, Abdulkadir. Hukum Dan Penelitian Hukum. Bandung - Indonesia: Citra Aditya Bakti, 2004.

Mywapblog. "Karakteristik Dan Ciri-Ciri Pedofilia.” Xiotwo.Mywapblog.Com.

N.D, Mukti Fajar, and Yulianto Achmad. Dualisme Penelitian Hukum Normatif Dan Empiris. Yogyakarta - Indonesia: Pustaka Pelajar, 2010.

Nawawi Arief, Barda. Bunga Rampai Kebijakan Hukum Pidana. Bandung Indonesia: FH Universitas Katolik Parahyangan, 2013.

—. Kebijakan Kriminal (Criminal Policy). Bandung - Indonesia: FH 
Universitas Katolik Parahyangan, 2013.

Peter, Salim, and Salim Yenny. Kamus Bahasa Indonesia Kontemporer. Edisi Pert. Jakarta - Indonesia: Modern English Press, 1991.

Prabowo, Ajie Gusti. "Diva Yang Diperkosa Dan Dibunuh Bersama Adiknya Baru Kelas II SD." Tribunnews.Com.

Priyatno, Dwidja. Sistem Pelaksanaan Pidana Penjara Di Indonesia. Bandung Indonesia: Refika Aditama, 2006.

Raharjo, Satjipto. Penegakan Hukum: Suatu Tinjauan Sosiologis. Yogyakarta Indonesia: Genta Publishing, 2009.

Sambas, Nandang. Pembaharuan Sistem Pemidanaan Anak Di Indonesia. Yogyakarta - Indonesia: Graha Ilmu, 2010.

Satochid, Kartanegara. Hukum Pidana Bagian Satu. Jakarta - Indonesia: Balai Lektur Mahasiswa, 2001.

Scribd.com. "Definisi Pedofilia." Scribd.Com.

Shidqiyyah, Septika. "5 Kasus Pemerkosaan Anak Di Bawah Umur Ini Bikin Geram Masyarakat!” Brilio.Net.

Sholehuddin. Sistem Sanksi Dalam Hukum Pidana. Kota Besar - Indonesia: Raja Grafindo Persada, 2002.

Soekanto, Soerjono. Pengantar Penelitian Hukum. Jakarta - Indonesia: Universitas Indonesia (UI Press), 2007.

Solehuddin, M. Sistem Sanksi Dalam Hukum Pidana Ide Dasar Double Track System Dan Implementasinya. Jakarta - Indonesia: Raja Grafindo Persada, 2003.

Sudarto. Hukum Dan Hukum Pidana. Bandung - Indonesia: Alumni, 1977.

Hukum Pidana Dan Perkembangan Masyarakat "Kajian Terhadap Pembaharuan Hukum Pidana.” Bandung - Indonesia: Sinar Baru, 1983.

Sutan, Zanti Arbi, and Ardhana Wayan. Rancangan Penelitian Kebijakan Sosial. Jakarta - Indonesia: Pustekkom Dikbud dan CV Rajawali, 1984.

Vioslav, Stojanovksi. "Surgical Castration of Sex Offenders and Its Legality: The Case of the Czech Republic." Theoretical Legal Sciences IV, no. Departemen Of Criminal Law (n.d.): 4.

Winarta, H. Frans. "Evaluasi Peranan Profesi Advokat Dalam Pemberantasan Korupsi." Majalah Desain Hukum. Jakarta - Indonesia, November 2011.

Zulfa, Eva Achjani. Pergeseran Paradigma Pemidanaan. Bandung - Indonesia: Lubuk Agung, 2011. 